\title{
ANALISIS KEMAMPUAN SISWA SMP DALAM MENERJEMAHKAN SOAL CERITA KEDALAM MODEL MATEMATIKA DAN PENYELESAIANNYA
}

\author{
Dian Lestari ${ }^{\text {I) }}$, Desi Patrianca Raya ${ }^{2)}$ \\ Pendidikan Matematika FKIP Unidayan Baubau ${ }^{1), 2)}$ \\ dian7lestari@gmail.com ${ }^{1)}$,deshypatriancaraya17@gmail.com ${ }^{2)}$
}

\begin{abstract}
Abstrak
Tujuan dari penelitian ini adalah untuk mendiskripsikan sejauh mana kemampuan siswa SMP dalam menerjemahkan soal-soal cerita ke dalam model matematika dan penyelesaiannya. Penelitian ini merupakan penelitian kualitatif dengan pendekatan deskriptif kualitatif.Sumber data dalam penelitian ini adalah siswa kelas VIII ${ }_{B C}$ SMP Negeri 2Buton Tengah tahun ajaran 2017/2018 yang berjumlah 21 siswa. Instrument dan teknik pengumpulan data yang digunakan adalah tes dan wawancara.Teknik analisis mengacu pada model reduksi data, menyajikan data dan menarik kesimpulan. Hasil penelitian menunjukkan tingkat kemampuan siswa dalam menerjemahkan soal cerita ke dalam model matematika untuk kemampuan verbal tegolong sedang dilihat dari presentasi hasil tes siswa dalam menyelesaikan soal cerita yaitu mencapai $65,67 \%$. Sedangkan kemampuan numeriknya tergolong rendah dilihat dari presentasi hasil tes siswa mencapai $19,40 \%$. Kemudian untuk kemampuan menafsirkan juga tergolong rendah dilihat dari presentasi hasil tes siswa mencapai $14,93 \%$.
\end{abstract}

Kata kunci: analisis kemampuan siswa, menerjemahkan soal cerita

\begin{abstract}
The objective of this research was to describe how far the ability of junior high school students in interpreting story problems into Mathematics model and its solution. This research was qualitative research with qualitative descriptive approach. Source of data in this research was students at class $V I_{B C}$ of SMP Negeri 2 Buton Tengah in the school year of 2017/2018 which consisted of 21 students. Instruments and technique of data collection used were test and interview. Technique of data analysis referred to model of data reduction data presentation, and concluding. Research outcome indicated the level of students' ability in interpreting story problems into Mathematics model for verbal ability was categorized as moderate seen by the percentage of students' test result in finishing story problems was 65.67\%. while their numeric ability was categorized as low seen by the percentage of students' test result was $19.40 \%$. Then, for the ability of interpreting was categorized as low seen by the percentage of students' test result was $14.93 \%$.
\end{abstract}

Keywords: students ability analysis, interpreting story problems

\section{PENDAHULUAN}

Soal cerita merupakan salah satu bentuk soal matematika yang memuat aspek kemampuan untuk membaca, menalar, menganalisis serta mencari solusi.Untuk itu siswa di tuntut dapat menguasai kemampuan-kemampuan dalam menyelesaikan soal cerita matematika tersebut.Kemampuan membaca digunakan untuk menerjemahkan masalah, sedangkan menalar untuk mengetahui maksud permasalahan yang diberikan, kemudian kemampuan menganalisis langkah-langkah penyelesaian serta menerapkan konsep-konsep matematika dalam menyelesaikan permasalahan.

Soal cerita matematika sangat berperan dalam kehidupan sehari-hari siswa, karena soal tersebut mengedepankan permasalahanpermasalahan real yang sesuai dengan kehidupan sehari-hari, namun banyak guru yang mengeluh karena rendahnya kemampuan siswa dalam mengerjakan soal cerita.Hal ini terlihat dari banyaknya kesalahan siswa dalam mengerjakan soal-soal cerita sehingga prestasi matematika siswa rendah. Salah satu penyebab siswa tidak mampu mengerjakan soal cerita adalah mereka belum mengerti apa yang diketahui dan apa yang ditanyakan dalam soal cerita tersebut. Kesulitan siswa dalam menentukan suatu penyelesaian bukanlah diakibatkan karena siswa tidak menguasai langkah-langkah dalam menyelesaikan suatu soal cerita namun lebih 
Dian Lestari, Desi Patrianca Raya

cenderung kepada kesulitan siswa untuk memaknai soal tersebut.

Berdasarkan uraian di atas, maka penulis mengadakan penelitian yang berjudul analisis kemampuan siswa SMP dalam menerjemahkan soal cerita ke dalam model matematika dan penyelesaiannya.

Rumusan masalah dalam penelitian ini adalah bagaimana kemampuan siswa dalam menerjemahkan soal-soal cerita kedalam model matematika dan penyelesaiannya? Tujuan dari penelitian ini adalah untuk mendeskripsikan kemampuan siswa SMP dalam menerjemahkan soal-soal cerita ke dalam model matematika dan penyelesaiannya.

Penelitian ini diharapkan dapat memberi sumbangan pemikiran terhadap upaya meningkatkan kemampuan siswa dalam menyelesaiakan soal cerita ke dalam bentuk matematika serta cara penyelesaiannya.

\section{METODE PENELITIAN}

\section{Jenis Penelitian}

Penelitian ini merupakan penelitian kualitatif dengan pendekatan deskriptif kualitatif, artinya menggambarkan atau mendeskripsikan kejadian-kejadian yang menjadi pusat perhatian (kemampuan pemecahan masalah, gaya belajar siswa) secara kualitatif dan berdasar data kualitatif. Data yang dihasilkan nantinya berupa kata-kata atau ucapan-ucapan yang diperoleh dari hasil wawancara dan tulisan atau bilangan yang diperoleh dari hasil wawancara.

\section{Subjek Penelitian}

Subjek dalam penelitian ini adalah siswa kelas VIII $_{\text {BC }}$ SMP Negeri 2Buton Tengah tahun ajaran 2017/2018 yang berjumlah 21 siswa.Keseluruhan siswa tersebut merupakan subjek tes kemampuan menerjemahkan soal cerita kedalam model matematika.

\section{Instrument dan Teknik Pengumpulan Data}

Instrumen dalam penelitian ini adalah tes diagnostik dan pedoman wawancara. Teknik pengumpulan data yang digunakan untuk mendapatkan data dalampenelitian ini adalah sebagai berikut.

Tes

Tes digunakan untuk memperoleh data tentang kemampuan siswa dalam menerjemahkan soal cerita kedalam model matematika dan penyelesaiannya, serta mengetahui letak kesulitansiswa dalam menyelesaikan soal cerita.Soal yang digunakan dalam tes iniadalah soal-soal yang berbentuk soal cerita pada pokok bahasan sistem persamaan linear dua variabel yang disusun oleh peneliti dan dikonsultasikan dengan dosen pembimbing dan guru mata pelajaran matematika kelas VIII SMP Negeri 2 Buton Tengah.

Wawancara

Dalam melakukan wawancara, peneliti perlu mendengarkan secara teliti dan mencatat atau menggunakan alat rekaman tentang apa yang dikemukakan oleh sumber data.

\section{Teknik Analisis Data}

Teknik analisis data yang dilakukan dalam penelitian akan dianalisis dengan mengacu pada model reduksi data, menyajikan data dan menarik kesimpulan. 1) Reduksi data dapat diartikan sebagai proses penyeleksian, menajamkan, menfokuskan dan menyerderhanakan data yang diperoleh, membuang data yang tidak perlu dari hasil wawancara. Dari data tersebut lalu disederhanakan sehingga dapat ditentukan faktor penyebab kesalahan siswa. 2) Penyajian data dilakukan dalam bentuk mengorganisasikan dan menyusun data menjadi informasi bermakna sehingga mudah untuk menarik kesimpulan. 3) Penarikan kesimpulan dilakukan setelah semua data terkumpul. Kesimpulan ini mengenai kemampuan siswa menerjemahkan soal cerita pada setiap pemahaman siswa dalam menyelesaikan soal.

\section{HASIL PENELITIAN DAN PEMBAHASAN}

\section{Hasil Penelitian}

Analisis kemampuan siswa menyelesaikan soal cerita

\section{Analisis jawaban siswa 1}

Analisis kemampuan siswa pada tahap kemampuan verbal

Siswa telah menuliskan apa yang di ketahui tetapi masih kurang tepat dan tidak menuliskan apa yang ditanyakan.

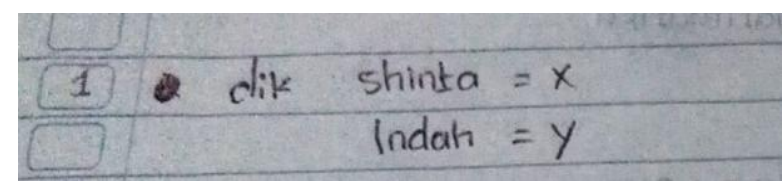

Gambar 1. jawaban siswa 1 pada tahap kemampuan verbal 
Dian Lestari, Desi Patrianca Raya

Dari gambar di atas, diketahui bahwa siswa keliru dalam menuliskan apa yang diketahui, seharusnya siswa menuliskan diketahui shinta membeli $2 \mathrm{~kg}$ apel dan $1 \mathrm{~kg}$ jeruk $=\mathrm{Rp} 38.000$, indah membeli $2 \mathrm{~kg}$ apel dan $3 \mathrm{~kg}$ jeruk $=\mathrm{Rp}$ 64.000 dan masni membeli $3 \mathrm{~kg}$ apel dan $1 \mathrm{~kg}$ jeruk, serta siswa keliru dalam menuliskan pemisalanya seharusnya siswa memisalkan $1 \mathrm{~kg}$ apel sebagai $x$ dan $1 \mathrm{~kg}$ jeruk sebagai $y$ tetapi siswa sudah mampu menuliskan apa yang ditanyakan. Namun, setelah melakukan wawancara siswa dapat menyebutkan apa yang diketahui dan ditanyakan soal, dalam hal ini kemapuan verbalnya terpenuhi. Pada soal nomor 1 ini sebanyak 2 orang siswa mengalami hal yang sama yakni subjek penelitian 2 dan 15 serta ada juga siswa yang tidak menjawab pada soal nomor 1 ini sebanyak 1 orang siswa yakni subjek penelitian 6.

Analisis kemampuan siswa pada tahap kemampuan numerik

Siswa mampu menuliskan model matematika tetapi tidak dapat menyelesaikan langkah-langkah penyelesaian.

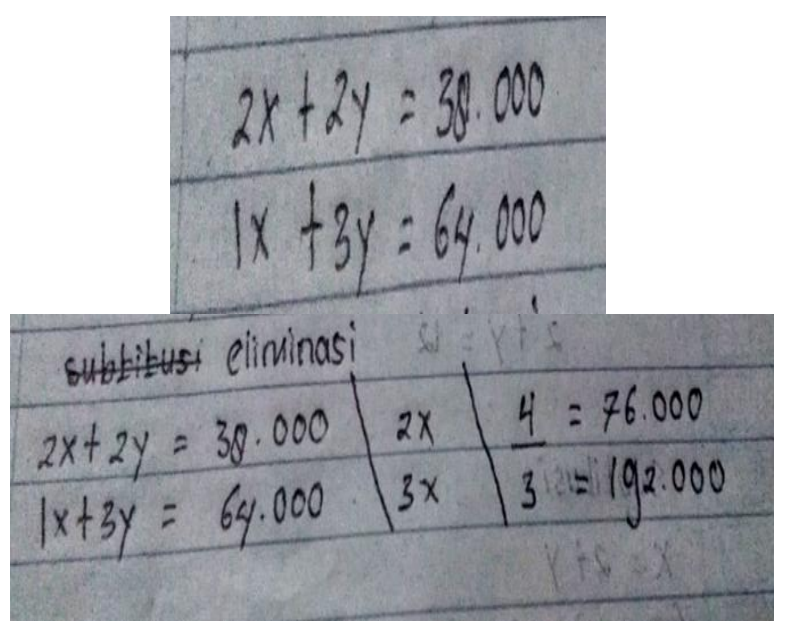

Gambar 2. jawaban siswa 1 pada tahap kemampuan numerik

Jawaban di atas adalah jawaban siswa yang mampu menuliskan model matematika tetapi salah dalam menyelesaikan operasi aljabar dan tidak menyelesaiakan langkah-langkah penyelesaian. Pada soal nomor 1 Sebanyak 10 siswa yang mengalami hal yang sama pada tahap ini yaitu subyek 2, 5, 7, 9, 10, 14, 15, 17, 18, dan 20 serta ada siswa yang tidak menjawab pada soal nomor 1 ini sebanyak 1 orang siswa yakni subjek penelitian 6 .
Analisis kemampuan siswa pada tahap

kemampuan menafsirkan

Siswa tidak menuliskan hasil akhir dari soal yang dikerjakan.

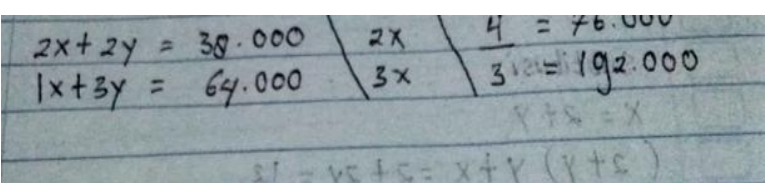

Gambar 3. jawaban siswa 1 pada tahap kemampuan menafsirkan

Siswa tidak menuliskan hasil akhir dari soal yang dikerjakan dan tidak menyimpulkannya. Pada tahap ini sebanyak 11 siswa yang mengalami hal yang sama yaitu subjek 2, 5, 6, 7, $8,9,10,12,14,17$ dan 18.

\section{Analisis jawaban siswa 2}

Analisis kemampuan siswa pada tahap kemampuan verbal

Siswa telah menuliskan apa yang di ketahui tetapi masih kurang tepat dan menuliskan apa yang ditanyakan.

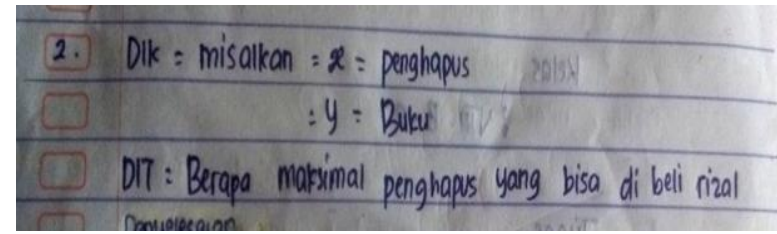

Gambar 4. jawaban siswa 2 pada tahap kemampuan verbal

Dari gambar di atas, diketahui bahwa siswa keliru dalam menuliskan apa yang diketahui, seharusnya siswa menuliskan diketahui doni membeli 4 penghapus dan 6 buku $=\operatorname{Rp} 36.800$, sidin membeli 2 penghapus dan 8 buku $=\mathrm{Rp}$ 45.400 dan rizal membeli 3 sejumlah dan 10 buku $=57.000$, tetapi siswa sudah benar dalam menuliskan pemisalanya dan menuliskan apa yang ditanyakan. Namun, setelah melakukan wawancara siswa dapat menyebutkan apa yang diketahui dan ditanyakan soal, dalam hal ini kemapuan verbalnya terpenuhi. Pada soal nomor 2 ini sebanyak 4 orang siswa mengalami hal yang sama yakni subjek penelitian 3, 4, 8, dan 10 serta ada juga siswa yang tidak menjawab pada soal nomor 2 ini sebanyak 10 orang siswa yakni subjek penelitian $5,6,7,9,11,12,13,14,16$, dan 17. 
Dian Lestari, Desi Patrianca Raya

Analisis kemampuan siswa pada tahap

kemampuan numerik

Siswa menuliskan model matematika tetapi salah dalam penyelesaian.

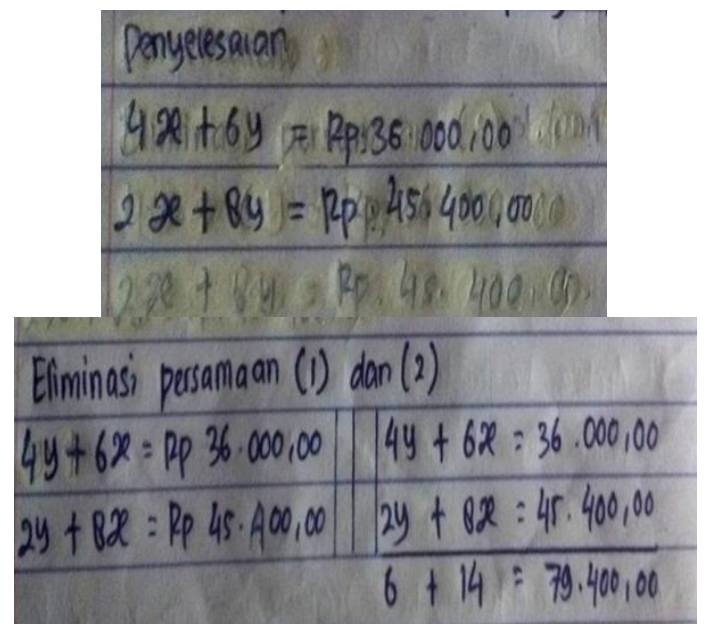

Gambar 5. jawaban siswa 2 pada tahap kemampuan numerik

Gambar di atas adalah jawaban siswa yang menuliskan model matematika tetapi salah dalam menyelesaikan langkah-langkah penyelesaian soal sehingga hasil yang diperoleh salah.Kesalahan tersebut diakibatkan kurangnya pemahaman siswa dalam menyelesaiakan soal. Sebanyak 5 siswa mengalami hal yang sama pada tahap ini yaitu subyek 3, 8, 15, 18 dan 20 serta ada juga siswa yang tidak menjawab pada soal nomor 2 ini sebanyak 11 orang siswa yakni subjek penelitian $5,6,7,8,9,10,11,12,13,14$, 16, dan 17.

Analisis kemampuan siswa pada tahap kemampuan menafsirkan

Siswa kurang tepat dalam menyimpulkan jawaban akhir.

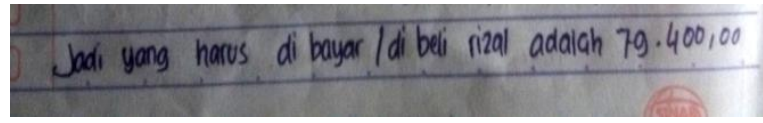

Gambar 6. jawaban siswa 2 pada tahap kemampuan menafsirkan

Gambar di atas adalah jawaban siswa menyimpulkan jawaban akhir tetapi kurang tepat.Kesalahan ini dikarenakan siswa tidak teliti dalam menjawab. Sebanyak 2 siswa mengalami hal yang sama yaitu subyek 4 dan 20 serta ada juga siswa yang tidak menjawab pada soal nomor 2 ini sebanyak 11 orang siswa yakni subjek penelitian $5,6,7,8,9,10,11,12,13,14,16$, dan 17.
Analisis jawaban siswa 3

Analisis kemampuan siswa pada tahap

kemampuan verbal

Siswa telah menuliskan apa yang di ketahui tetapi masih kurang tepat dan menuliskan apa yang ditanyakan

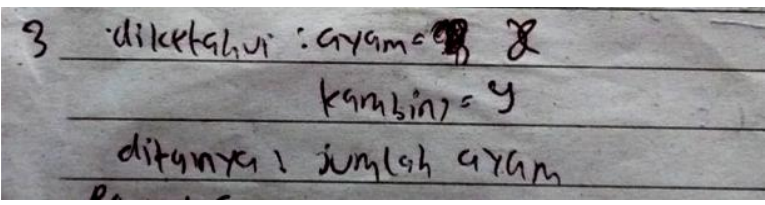

Gambar 7. jawaban siswa 3 pada tahap kemampuan verbal

Dari gambar di atas, diketahui bahwa siswa keliru dalam menuliskan apa yang diketahui, seharusnya siswa menuliskan diketahui paman alex memiliki 45 hewan tenak yang terdiri dari ayam dan kambing dengan jumlah kaki hewan ternak paman 100 kali tetapi siswa sudah benar dalam menuliskan pemisalanya dan menuliskan apa yang ditanyakan. Namun, setelah melakukan wawancara siswa dapat menyebutkan apa yang diketahui dan ditanyakan soal, dalam hal ini kemapuan verbalnya terpenuhi. Pada soal nomor 3 ini sebanyak 8 orang siswa mengalami hal yang sama yakni subjek penelitian 5, 6, 9, 13, 14, 17, 18 , dan 20 serta ada pula siswa yang mampu dalam menuliskan apa yang diketahui tetapi tidakmenuliskan apa yang ditanyakan sebanyak 1 orang siswa subjek penelitian 12 .

Analisis kemampuan siswa pada tahap kemampuan numerik

Siswa tidak dapat membuat model matematika dan langkah-langkah penyelesaian.

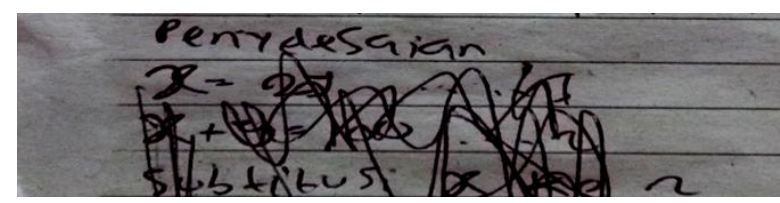

Gambar 8. jawaban siswa 3 pada tahap kemampuan numerik

Gambar di atas adalah jawaban siswa yang kesulitan dalam membuat model matematika dan langkah-langkah penyelesaiannya. Sebanyak 15 siswa mengalami hal yang sama yaitu subyek 1, $2,3,4,8,10,11,12,13,15,16,18,19,20$, dan 21. 
Dian Lestari, Desi Patrianca Raya

Analisis kemampuan siswa pada tahap kemampuan menafsirkan

Siswa tidak mampu menunjukan hasil akhir dari penyelesaian soal. Pada tahap ini sebanyak 19 siswa yang mengalami hal yang sama yaitu subjek $1,2,3,4,5,6,7,8,9,10,11,12,13,15$, 16, 18, 19, 20, dan 21.

Untuk lebih jelasnya maka peneliti membuat tabel untuk mengetahui kemampuan siswa dalam menyelesaikan soal cerita.Berikut adalah tabel kemampuan siswa menyelesaikan soal cerita berdasarkan kemampuan verbal.Kemampuan numerik, dan kemampuan menafsirkan, dari tabel dapat dilihat siswa yang berkemampuan kurang (subjek 1), sedang (subjek 2) dan tinggi (subjek 3).

Tabel 1. Kemampuan Siswa Dalam Menyelesaiakan Soal Cerita Pada Butir Soal No 1, 2, 3, dan 4

\begin{tabular}{|c|c|c|c|c|}
\hline $\begin{array}{c}\text { Nomor } \\
\text { Soal }\end{array}$ & $\begin{array}{c}\text { Kemampuan } \\
\text { Menyelesaikan } \\
\text { Soal } \\
\end{array}$ & $\begin{array}{c}\text { Subjek } \\
1\end{array}$ & $\begin{array}{c}\text { Subjek } \\
2\end{array}$ & $\begin{array}{c}\text { Subjek } \\
3\end{array}$ \\
\hline \multirow{3}{*}{1} & Verbal & - & - & - \\
\hline & Numerik & - & - & $\checkmark$ \\
\hline & Menafsirkan & - & - & $\checkmark$ \\
\hline \multirow{3}{*}{2} & Verbal & - & - & - \\
\hline & Numerik & - & - & $\checkmark$ \\
\hline & Menafsirkan & - & - & - \\
\hline \multirow{3}{*}{3} & Verbal & - & - & - \\
\hline & Numerik & - & - & - \\
\hline & Menafsirkan & - & - & - \\
\hline \multirow{3}{*}{4} & Verbal & - & - & - \\
\hline & Numerik & - & $\checkmark$ & $\checkmark$ \\
\hline & Menafsirkan & $\checkmark$ & $\checkmark$ & $\checkmark$ \\
\hline
\end{tabular}

\section{Pembahasan}

Berdasarkan analisis tes dan analisis wawancara yang telah dilakukan sebelumnyadi peroleh hasil tes kemampuan menerjemahkan soal cerita ke dalam model matematika dan penyelesaiannya siswa kelas VIII $_{\text {B-C }}$ dalam setiap soal yang telah dikategorikan dalam 3 tingkat kemampuan menyelesaiakan soal cerita seperti pada tabel berikut .

Tabel 2. Tingkat Kemampuan Siswa Pada Butir Soal

\begin{tabular}{|c|c|c|c|c|c|}
\hline \multirow{2}{*}{$\begin{array}{c}\text { Jenis } \\
\text { Kemampuan }\end{array}$} & \multicolumn{4}{|c|}{ Nomor Soal } & \multirow{2}{*}{ Pesentase } \\
\hline & 1 & 2 & 3 & 4 & \\
\hline $\begin{array}{l}\text { Kemampuan } \\
\text { Verbal }\end{array}$ & 16 & 4 & 8 & 16 & $65,67 \%$ \\
\hline $\begin{array}{l}\text { Kemampuan } \\
\text { Numerik }\end{array}$ & 1 & 1 & 0 & 11 & $19,40 \%$ \\
\hline $\begin{array}{l}\text { Kemampuan } \\
\text { Menafsikan }\end{array}$ & 1 & 0 & 0 & 9 & $14,93 \%$ \\
\hline
\end{tabular}

Tabel di atas menunjukan bahwa tingkat kemampuan siswa, dalam hal ini kemampuan verbal mencapai $65,67 \%$, kemampuan numerik mencapai $19,40 \%$ dan kemampuan menafsirkan mencapai $14,93 \%$.

Berdasarkan uraian di atas, maka kemampuan siswa dalam menyelesaikan soal cerita masih tergolong rendah dikarenakan siswa masih belum memahami maksud dari soal yang disajikan baik itu soal nomor 1, 2, 3, dan 4, hal ini disebabkan oleh beberapa faktor yaitu: 1) Kurangnya pemahaman siswa pada materi. 2) Siswa kurang teliti dalam menyelesaikan soal. 3) Kurangnya pemahaman siswa dalam langkahlangkah penyelesaian. 4) Kurangnya kemampuan siswa dalam operasi aljabar

\section{KESIMPULAN DAN SARAN}

\section{Kesimpulan}

Berdasakan hasil penelitian dan pembahasan, maka dapat diambil kesimpulan bahwa tingkat kemampuan siswa dalam menerjemahkan soal cerita kedalam model matematika untuk (1) kemampuan verbal tergolong sedang dilihat dari presentasi hasil tes siswa dalam menyelesaikan soal cerita yaitu mencapai $65,67 \%$ (2) kemampuan numeriknya tergolong rendah dilihat dari presentasi hasil tes siswa mencapai $19,40 \%$, dan (3) kemampuan menafsirkan juga tergolong rendah dilihat dari presentasi hasil tes siswa mencapai $14,93 \%$.

\section{Saran}

Berdasarkan hasil penelitian yang diperoleh, maka saran dari peneliti adalah sebagai berikut. 1) Sebaiknya siswa lebih ditekankan agar dapat menguasai langkah-langkah penyelesaian soal matematika dalam bentuk cerita. 2) Dalam mengerjakan soal, guru harus membiasakan siswa untuk mengerjakan soalsecara sistematis dimulai dari apa yang diketahui, apa yang ditanyakankemudian jawab.

\section{DAFTAR PUSTAKA}

[1] Aswati.(2017). analisis tingkat kemampuan menyelesaikan soal cerita dalam pembelajaran matematika materi bilangan bulat pada siswa kelas $V$ SD Negeri 1 popalia.(Skripsi). Tidak Diterbitkan. Baubau. Universitas Dayanu Iksanuddin.

[2] Hidayati.(2012). Analisis Kemampuan Siswa Smp Dalam Menerjemahkan Soal Cerita Ke 
Dian Lestari, Desi Patrianca Raya

Dalam Model Matematika Dan

Penyelesaiannya.(Skripsi).Universitas

Muhammadiyah Surakarta.

[3] Ihsan, W.M (2016). Analisis Kemampuan Menyelesaikan Soal Cerita MatematikaDitinjau dari Kemampuan Verbal pada Siswa Kelas VII SMPMuhammadiyah Se-Kota Makassar.Suska Journal of Mathematics Education.Vol 2.No. 2.111-112.

[4] NCTM, (2000).Principles and Standards for School Mathematics.USA: NCTM.

[5] Neli, Dasriu. (2017). Analisis Kesalahan Siswa Dalam Menyelesaiakan Soal Cerita Matematika Kelas VIII A SMP Negeri 3 Baubau Pada Materi Sistem Persamaan Linear Dua Variabel Berdasarkan Metode Analisis Kesalahan Newman. (skripsi).Tidak Diterbitkan. Baubau. Universitas Dayanu Iksanuddin.

[6] Nuharini, Dewi \& Tri Wahyuni. (2008). Matematika Konsep dan Aplikasinya Untuk Kelas VIII SMP Dan MTs. Jakarta: Pusat Perbukuan Pendidikan Nasional.

[7] Romadhina, Dian. (2007). Pengaruh Kemampuan Penalaran dan Kemampuan Komunikasi Matematik terhadap Kemampuan Menyelesaikan Soal Cerita Pada Pokok Bahasan Bangun Ruang Sisi Lengkung Siswa Kelas IX SMP Negeri 29 Semarang Melalui Model Pembelajaran Pemecahan Masalah.(skirpsi).Semarang. Universitas Negeri Semarang.

[8] Sugiyono. (2007). Metode penelitian pendidikan pendekatan kuantitatif, kualitatif dan $R \& D$. Bandung: Alfabeta.

[9] Widyaningrum, A,Z (2015). Analisis Kesulitan Siswa DalamMengerjakansoal Cerita MatematikaMateri Aritmatika Sosial Ditinjau DariGaya Belajar Siswa Kelas VII Smp Negeri 5Metro.JurnalIqra Vol. 01 No. 02.171-172.

[10] Yudharina, Pretty. (2015). Meningkatkan Kemampuan Menyelesaikan Soal Cerita Matematika Siswa Kelas V Sd Negeri Mejing 2 Melalui Model Pembelajaran Creative Problem Solving.(skripsi). Yokyakarta.Universitas Negeri Yogyakarta. 